\section{Nadja Dobnik}

Ekonomska

fakulteta $v$

Ljubljani

\title{
KAKO SMO PROGRAMIRALI UČBENIK ZA ŠTUDIJ NA DALJAVO?
}

\section{Primer programiranja poslovnega italijanskega jezika za študij na daljavo}

Učenje in poučevanje poslovnega tujega jezika na daljavo je pri nas še redkost, ker so vprašanja programiranja in načrtovanja tesno povezana s specifičnimi organizacijskimi in izvedbenimi vprašanji. Izkušnje Ekonomske fakultete $v$ Ljubljani so spodbudne in programiranje poslovnega italijanskega jezika nakazuje nekatere ključne dileme sodobnega jezikovnega izobraževanja odraslih. Programiranje poslovnega italijanskega jezika v okviru študijskega programa Visoke poslovne šole na Ekonomski fakulteti v Ljubljani je zanimiv tudi zato, ker gre za jezikovni program, ki se kot študijski predmet izvaja $\mathrm{v}$ treh različnih oblikah: v okviru rednega študija ter izrednega študija in študija na daljavo. Po petih letih intenzivnega dela s študenti se je potrdilo, da je jasen koncept vsebin na podlagi jasno opredeljenih ciljev pogoj in zagotovilo za to, da se ne glede na razlike $v$ izvedbi izobraževanja dosežejo enaki rezultati.

\section{Posebnosti študijskega programa Visoke poslovne šole}

Ekonomska fakulteta $v$ Ljubljani je uvedla program Visoke poslovne šole leta 1994 kot redni študij, leta 1995 pa kot izredni študij v Ljubljani in $v$ obliki študija na daljavo $v$ treh centrih (Nova gorica, Trebnje in Ptuj). Študijski program prvega letnika je obsegal ${ }^{1}$ deset predmetov, od teh dva poslovna tuja jezika (angleščina, nemščina, francoščina in italijanščina).

$\mathrm{V}$ vseh treh primerih (redni študij, izredni študij in študij na daljavo) gre za enak študijski program z enakim predmetnikom, bistvene razlike so le $\mathrm{v}$ izvedbi programa, predvsem $v$ organizaciji študija in številu skupinskih srečanj ter konzultacij. Koncept vsebin za posamezen predmet je zato skupen za vse študente, za vse skupine je predvidena 
tudi enaka končna evalvacija v obliki enakega končnega testa.

Posebnost izvajanja predmetov Visoke poslovne šole je $v$ tem, da za redne študente potekajo predavanja in vaje $\mathrm{v}$ polnem obsegu (na primer 90 ur), za izredne študente je število predavanj in vaj skrčeno na tretjino $v$ primerjavi z obsegom pri rednem študiju (30 ur), za študente na daljavo pa so za vse predmete pripravili študijsko gradivo kot nadomestilo za predavanja in organizirali redna skupinska srečanja za pomoč pri študiju. Za redne študente potekajo vsi predmeti enega semestra sočasno, izpitni roki za vse predmete so predvideni ob koncu semestra. Izredni študenti in študenti na daljavo pa študirajo po modularnem principu, tako da si predmeti sledijo drug za drugim, izpit iz posameznega predmeta pa je mogoče oprảvljati takoj ob koncu posameznega modula.

Pri študiju na daljavo se je torej pri vseh predmetih pojavila potreba po pripravi ustreznega študijskega gradiva, s katerim bi študenti lahko predelali snov in se pripravili na izpit tudi brez predavanj ter neposrednega dela s predavateljem. Pri tem smo se predavatelji odločali med dvema možnostma: nekateri so (svojemu) učbeniku dodali vodnik po predmetu, s katerim lahko študenti predelujejo snov iz učbenika, drugi pa so napisali povsem novo, zaokroženo gradivo, ki vsebuje novo učno snov in tudi navodila za študij.

Poleg posebne pozornosti, ki je bila posvečena pripravi gradiva, je bila predvidena tudi posebna organizacija: med potekom posameznega predmeta so bila v študijskem središču predvidena tedenska srečanja $\mathrm{Z}$ mentorjem (tutorjem), študenti pa so se lahko pred začetkom izvajanja predmeta in pred izpitom srečali tudi $s$ predavateljem nosilcem predmeta.

\section{IZHODIŠČA ZA PROGRAMIRANJE POSLOVNEGA ITALIJANSKEGA JEZIKA}

Program Visoke poslovne šole je usmerjen v prakso. Temu prilagojeni so bili tudi cilji posameznih predmetov. V primerjavi $\mathrm{z}$ univerzitetnim študijem ekonomije naj bi študijski program Visoka poslovna šola predvsem usposobil diplomante za takojšnjo korektno praktično uporabo strokovnih znanj, analitičnih postopkov in poslovnih tehnik (spletna stran EF). Vsebine naj bi bile

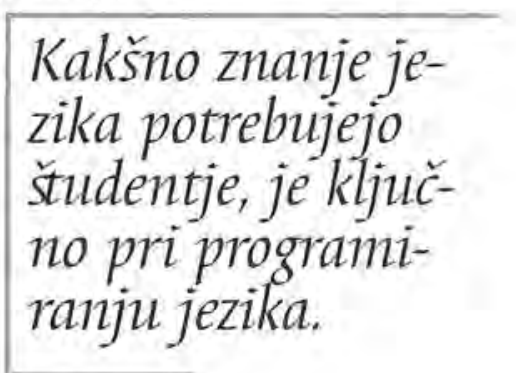
zato izrazito operativno naravnane.

Pri programiranju poslovnega italijanskega jezika so nas zato vodila predvsem naslednja vprašanja: kakšne poklicne dejavnosti naj bi opravljali bodoči diplomanti in kakšno znanje italijanskega jezika naj bi pri tem potrebovali, v kakšnih okoliščinah bodo nastopali in kdo bodo najverjetneje njihovi sogovorniki.

Glede na praktično naravnanost študijskega programa je bilo mogoče predvideti, da bo šlo predvsem za srečanja s tujimi partnerji na ravni sklepanja poslovnih dogovorov. Kot drugo možnost pa smo predvideli tudi možnost zaposlovanja naših diplomantov pri italijanskih delodajalcih, saj je večina študentov, ki se odločijo za italijanščino, s Primorske.

Prvi koncept učnih ciljev je nastal na podlagi predvidevanj o jezikovnih potrebah bodočih diplomantov, izkušenj pri delu $\mathrm{z}$ izrednimi študenti v okviru univerzitetnega programa, pa tudi usmeritev $\mathrm{v}$ poslovnem svetu. Domnevati je bilo mogoče, da bodo bodoči diplomanti potrebovali znanje italijanščine kot predstavniki podjetij pri srečanjih $\mathrm{z}$ italijanskimi partnerji in/ali pri iskanju zaposlitve pri italijanskih delo- 


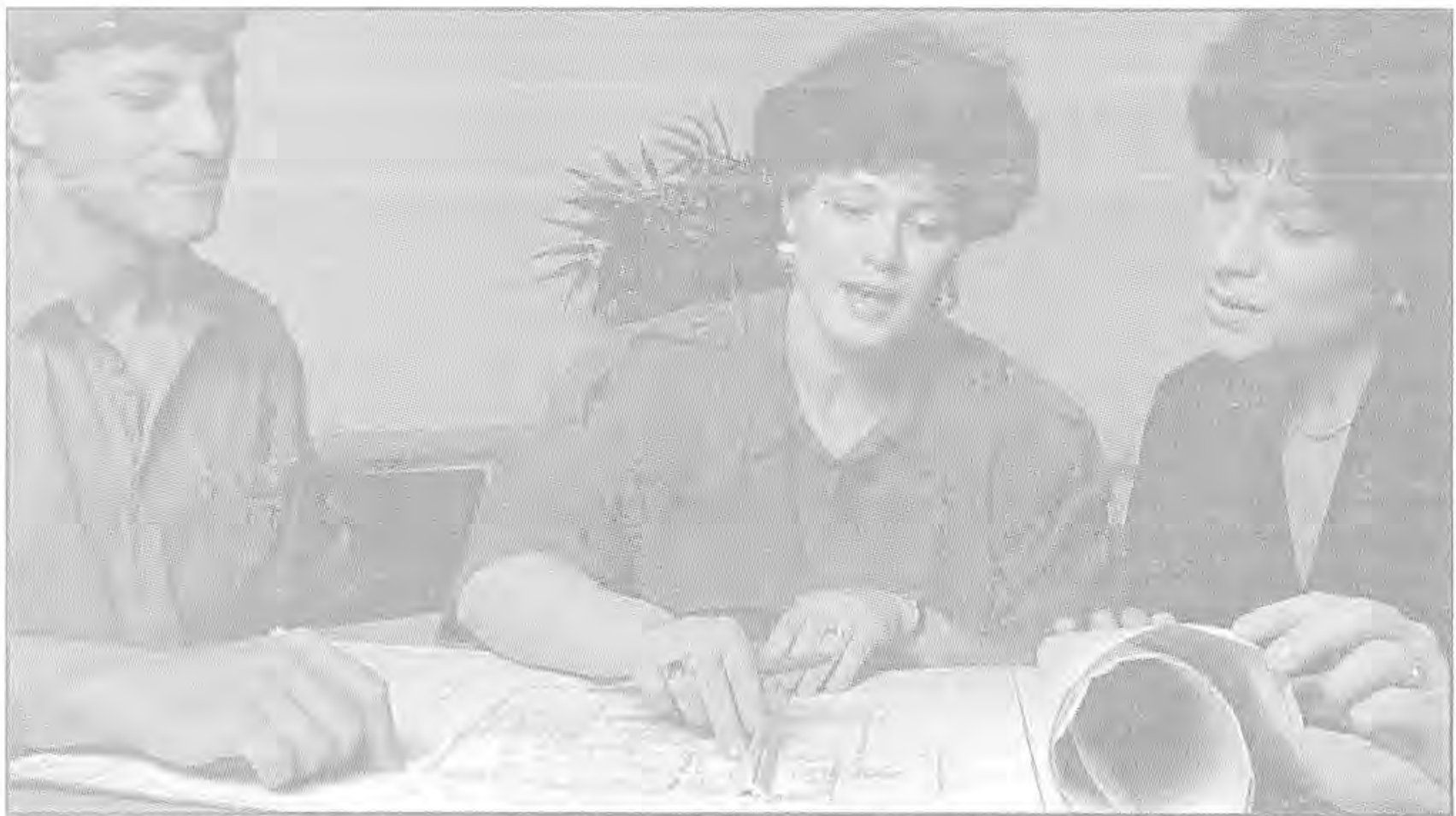

dajalcih. To je pomenilo, da morajo znati pisno ali po telefonu navezati stike $\mathrm{z}$ italijanskimi poslovneži in se dogovoriti za srečanje, ob srečanju predstaviti sebe, svoje sodelavce, svoje podjetje in izdelke, ki jih ponuja, da se morajo znati pogajati za ceno in pogoje prodaje pri neposrednih pogajanjih in v pisni obliki. Glede iskanja zaposlitve pa morajo znati napisati prošnjo za službo, lasten življenjepis in se pripraviti na razgovor za službo.

Med pripravo na pisanje gradiva je bilo mogoče le predpostavljati, kakšen bo dejanski profil študentov, za katere je treba pripraviti gradivo. Po primerjavi z izrednimi študenti na univerzitetnem programu smo predvidevali, da bo šlo za mlajše odrasle, stare od 20 do 30 let, pretežno ženske s Primorske, predvsem iz Nove Gorice in okolice (predvidevali smo namreč, da se bo večina študentov, vpisanih $v$ študijskem centru v Novi Gorici, odločila za italijanski jezik). Čeprav smo za vse tuje jezike predvideli, da morajo imeti študenti določeno predznanje (od 160 do 240 ur učenja), smo vedeli, da v praksi ne bo tako in da nekateri študenti ne bodo imeli (formalnega) predznanja. Zaradi bližine meje $\mathrm{z}$ Italijo in razširjenosti italijanščine smo sklepali, da bodo vsi študenti vsaj pasivno obvladali italijanščino, glede dejanskega poznavanja zakonitosti jezika pa je bilo mogoče pričakovati velike razlike. Te smo pričakovali tudi glede izobrazbe (od poklicne šole do štiriletne srednje šole ali gimnazije) in s tem povezano stopnjo razvitosti učnih navad in sposobnosti za samostojno učenje. Predpostavljali smo, da bo večina študentov zaposlenih, da bodo poznali poslovno okolje in imeli morda tudi določene izkušnje pri poslovanju s tujimi podjetji, predvsem pa, da bodo imeli po končanem študiju možnost delati na takih delovnih mestih, pri čemer bodo zaradi bližine meje $\mathrm{z}$ Italijo $\mathrm{v}$ stiku $\mathrm{z}$ italijanskimi podjetniki in poslovneži.

$\mathrm{Na}$ navedenih ugotovitvah je nastala shema 
učnih ciljev, ki izhajajo iz predpostavke, da mora znati študent:

1. navezati stike $\mathrm{z}$ italijanskimi partnerji in prositi za srečanje oziroma odgovoriti na povabilo za srečanje:

- pisno,

- po telefonu;

2. predstaviti sebe in svoje sodelavce:

- ob prihodu tujih partnerjev v podjetje,

- ob prihodu v tuje podjetje;

3. predstaviti svoje podjetje in njegovo dejavnost,vprašati za vse bistvene informacije o tujem podjetju in njegovi dejavnosti;

4. predstaviti izdelke in/ali storitve:

- ki jih njegovo podjetje ponuja,

- ki jih ponuja tuje podjetje;

5. pogajati se o ceni in drugih prodajnih pogojih za določen izdelek/storitev:

- na sestanku,

- po telefonu,

- v pisni obliki;

6. napisati prošnjo za službo, svoj življenjepis, pripraviti se na razgovor za službo.

Na podlagi tako zastavljenih učnih ciljev je nastal prvi okvirni koncept vsebin.

Da bo študent lahko dosegel zastavljene učne cilje, mora spoznati (razumeti, se naučiti, osvojiti itd.):

- vsebinske in oblikovne posebnosti poslovne korespondence (izrazi, vljudnostne fraze, jezikovna sredstva, splošne konvencije in pravila, oblikovne značilnosti ipd.);

- posebnosti sporazumevanja po telefonu (vljudnostne fraze, terminologija, splošna pravila in konvencije, bonton ipd.);

- kako lahko predstavi sebe in svoje sodelav- ce (komunikacijske funkcije, vljudnostne fraze, ravni jezika, protokol, bonton ipd.);

- kako in v kakšni obliki lahko predstavi svoje podjetje in njegovo dejavnost (strokovni izrazi, fraze, ubeseditve pri dajanju informacij in spraševanju ipd.);

- vrste in pravne oblike italijanskih podjetij (vrste, način poslovanja ipd.);

- kako in s kakšnimi jezikovnimi sredstvi lahko predstavi izdelek ali storitev (strokovni izrazi, ubeseditve ipd.);

- kako se na sestanku ali po telefonu dogovarja za ceno in prodajne pogoje (strokovni izrazi, fraze, jezikovna sredstva, splošne konvencije in poslovni bonton);

- kakšno funkcijo ima poslovna korespondenca pri dogovarjanju o ceni in prodajnih pogojih;

- vsebinske, jezikovne in oblikovne posebnosti poslovne korespondence (primeri dopisov; strokovni izrazi, vljudnostne fraze, jezikovna sredstva; splošne konvencije in pravila, oblikovne značilnosti ipd.);

- vsebinske, jezikovne in oblikovne posebnosti prošnje za službo in življenjepisa (vljudnostne fraze, principi strukturiranja podatkov, konvencije in pravila pri podajanju podatkov ipd.);

- kakšno funkcijo ima prošnja za službo in kakšno življenjepis;

- namen razgovora za službo, njegov potek, pravila in posebnosti.

Do te točke je programiranje potekalo na ravni teoretičnega, deduktivnega pristopa $\mathrm{k}$ opredelitvi ciljev in vsebin. Izhajali smo iz prepričanja, da mora biti osnovna struktura, 
"logična os" programa, zastavljena glede na splošna izhodišča študijskega programa in principe programiranja jezikovnih programov za posebne ciljne skupine, ne glede na obliko študija (redni, izredni študij, študij na daljavo).

Ta okvirna izhodišča so bila osnova že za delo $z$ rednimi študenti. Odločila sem se, da bo podlaga za delo $\mathrm{z}$ rednimi študenti učbenik italijanske avtorice Nicolette Cherubini "L 'italiano per gli affari" (1992), ki po zahtevnosti in vsebinsko ustreza večini meril. Delo z rednimi študenti je potekalo v llcbenik mora

imeti jasno definirane etapne in končne cilje. skupini, zato je bilo mogoče vrstni red poglavij prirediti glede na potrebe skupine: začeli smo s 6. lekcijo in snov predelali do 10 . lekcije (predstavitev podjetja, opis izdelka itd.), šele na koncu smo predelali prve tri lekcije (iskanje zaposlitve), ki so tudi sicer zahtevnejše (posebni registri jezika ipd.). Četrto in peto lekcijo (priporočila in razgovor za službo) pa smo izpustili.

Tak način preskakovanja $\mathrm{z}$ enega dela učbenika na drugega bi bil za študente na daljavo nespremenljiv, čeprav bi učbeniku dodali izčrpna navodila. Predavateljice tujih jezikov smo se pri pripravi gradiva za študij na daljavo odločile za različne rešitve: za angleški jezik smo $\mathrm{k}$ učbeniku angleške avtorice dodale poseben vodnik po predmetu, v katerem smo predstavile način dela in osmislile posamezne stopnje pri obravnavanju nove snovi, utrjevanju novih pojmov, dodale razlago in vaje za utrjevanje snovi ipd. Pri nemščini in italijanščini pa smo se odločile, da je najbolj smiselno pripraviti novo, zaokroženo gradivo.

Zaradi pomanjkanja časa smo se odločili, da prvo različico gradiva pripravimo na osnovi poglavij iz učbenika Nicolette Cherubini, ki vsebinsko ustrezajo tej ciljni skupini, jih didaktično priredimo, dopolnimo z novimi vajami in razlago ter povežemo $\mathrm{v}$ novo celoto.

\section{KONKRETIZACIJA VSEBIN IN PROGRAMIRANJE UČBENIKA}

$\mathrm{Na}$ osnovi okvirnih vsebinskih izhodišč in odločitve pripraviti posebno študijsko gradivo je bilo treba $v$ naslednji fazi te vsebine podrobno opredeliti in jih urediti $\vee$ zaokrožene učne enote.

Predvideni rok trajanja posameznega modula oziroma predmeta je bil določen na osem tednov, zato smo se odločili, da bo gradivo za poslovni italijanski jezik obsegalo sedem zaokroženih enot, ki naj bi jih študenti predelali $v$ sedmih do osmih tednih.

\section{Razčlenitev učne snovi na enote}

Predviden koncept vsebin je bilo treba razčleniti in povezati $\mathrm{v}$ sedem zaokroženih učnih enot, ki so morale biti med seboj smiselno povezane in se postopoma nadgrajevati ter skozi etapne učne cilje voditi k zaokroženi celoti. Podrobno je bilo treba določiti vsebino posameznih učnih enot in jasno opredeliti etapne cilje ter končni cilj vsake enote, določiti zaporedje enot in rdečo nit, ki jih bo povezovala, opredeliti notranjo strukturo, po kateri bodo učne enote zgrajene, in podcilje posameznih delov vsake učne enote.

Pri vsebinskem oblikovanju posameznih enot sem izhajala predvsem iz večletnih izkušenj pri delu z odraslimi slušatelji tujih jezikov in izrednimi študenti Ekonomske fakultete, pri delu v podjetju in v prevajalskem poklicu, pomembno izhodišče pa je bilo tudi poznavanje drugih ciljev študija Visoke poslovne šole in poglobljen primerjalni študij gradiva za učenje tujih jezikov. Tako je na podlagi prvega, okvirnega koncepta vsebin nastala shema učbenika. 


\section{Prva učna enota - Predstavitve (Presentazioni)}

Zajema različne poslovne okoliščine, v katerih se oseba predstavi in pove bistvene podatke o svojem delu, nalogah in funkcijah, ter okoliščine, v katerih predstavimo osebo drugi osebi. Gre za okoliščine, ki so na videz preproste, vendar povezane s poznavanjem vljudnostnih fraz, bontona, protokola in razvijanjem občutka za različne ravni jezika. Študent naj bi se seznanil $\mathrm{z}$ različnimi situacijami, v katerih se bo prvič ali ponovno srečal z italijanskimi kolegi, navadami in protokoli, značilnimi za srečanja, ter z vljudnostnimi frazami in izrazi, ki se uporabljajo $v$ italijanskem jeziku.

Cilj te enote je, da zna študent v različnih okoliščinah, ko se prvič ali ponovno sreča $\mathrm{Z}$ italijanskimi kolegi, pravilno ravnati, primerno predstaviti sebe in kolege.

\section{Druga učna enota - Uvod v poslovno korespondenco (Introduzione alla corrispondenza commerciale)}

Pomeni uvod v poslovno korespondenco. Večina stikov s tujimi partnerji poteka neosebno, na daljavo $-\mathrm{z}$ dopisi in po telefonu. Študent naj bi se seznanil $\mathrm{z}$ osnovnimi principi poslovne korespondence, vlogo ter pomenom, ki jo ima $\mathrm{v}$ sodobni poslovni komunikaciji, in $\mathrm{z}$ oblikovnimi ter vsebinskimi posebnostmi poslovnih dopisov $\mathrm{v}$ italijanskem jeziku.

Cilj te enote je, da zna študent pravilno oblikovati in sestaviti poslovni dopis in tudi že sam napisati kratek dopis.

\section{Tretja učna enota - Dogovarjanje za srečanje (Appuntamenti d'affari)}

Gre za uporabo znanja, pridobljenega v drugi enoti, $v$ novih okoliščinah, in sicer na primeru

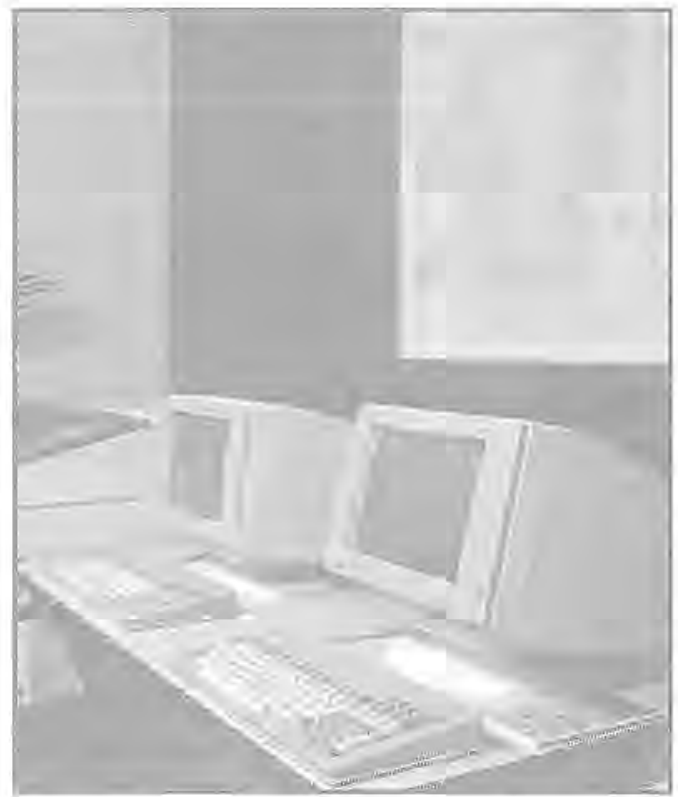

pisnega dogovarjanja za sestanek. Študent naj bi se seznanil s primeri dopisov, $v$ katerih tuji partner italijanskega kolega prosi za sestanek, ta pa v odgovoru sestanek potrdi in ga obvesti o podrobnostih srečanja. Obenem se študent seznani tudi $\mathrm{z}$ navadami, značilnimi za dogovarjanje za sestanke, in najpogostejšimi izrazi ter frazami, ki se $\mathrm{v}$ takih dopisih uporabljajo.

Cilj te enote je, da zna študent napisati kratek dopis, $v$ katerem predlaga srečanje, ali pa dopis, $v$ katerem predlog za srečanje potrdi.

\section{Četrta učna enota - Poslovna srečanja (Incontri d'affari)}

Pogovor za srečanje se nadaljuje v okoliščine prvega poslovnega srečanja med tujimi partnerji. Poleg osebne predstavitve je treba predstaviti svoje podjetje in spoznati podjetje, $\mathrm{s}$ katerim nameravamo sodelovati. Študent se seznani $\mathrm{z}$ načini in oblikami predstavitve podjetja in njegovega delovanja, najpogostejšimi vprašanji, na katera bo moral biti pripravljen odgovoriti, $\mathrm{z}$ jezikovnega vidika pa z načinom formuliranja vprašanj in frazami ter izrazi, ki se uporabljajo za 
predstavitev različnih vidikov delovanja podjetja.

Cilj te enote je, da zna študent različno predstaviti svoje podjetje in opisati njegovo dejavnost ter delovanje, obenem pa mora znati tuje partnerje vprašati o dejavnosti in posebnostih njihovega podjetja.

\section{Peta učna enota - Opis izdelka in postopka izdelave (Descrizioni di prodotti e procedimenti)}

Enota je vsebinsko razdeljena na dva dela in se od splošne predstavitve podjetja nadaljuje v predstavitev izdelka ali storitve, ki jo podjetje ponuja (prvi del), in opis izpeljave določenega postopka, bodisi postopka izdelave določenega izdelka, njegove uporabe bodisi načina izpeljave določene storitve (drugi del). Študent se najprej seznani z ubeseditvami in frazami za opis lastnosti in posebnosti določenega izdelka ali storitve (mere, teža, materiali, namen in področje uporabe, prednosti, cena), v nadaljevanju pa $z$ načinom sistematičnega opisa izpeljave določenegá postopka.

Cilj te enote je, da zna študent opisati izdelek ali storitev, ki jo ponuja tujemu partnerju, in predstaviti način izdelave, uporabe ali izpeljave postopka, ki je povezan $\mathrm{z}$ določenim izdelkom ali storitvijo.

\section{Šesta učna enota - Poslovna korespondenca (Corrispondenza commerciale)}

Od neposredne komunikacije med poslovnimi partnerji se vrne $\mathrm{h}$ korespondenci in študenta seznani $\mathrm{z}$ nekaterimi najpogostejšimi oblikami poslovnih dopisov, ki so povezani s povpraševanjem po določenem izdelku ali storitvi, ponudbo in naročilom. Študent spozna nekaj primerov takih dopisov in ubeseditve, ki se v italijanski poslovni korespondenci uporabljajo v zvezi z njimi.
Cilj te enote je, da zna študent napisati kratko povpraševanje, ponudbo ali naročilo.

\section{Sedma učna enota - Prošnje za službo (Domande d'impiego)}

Od prejšnjih enot se vsebinsko nekoliko razlikuje, saj s poslovnih stikov med italijanskimi in slovenskimi podjetji pride na področje iskanja zaposlitve pri italijanskem delodajalcu. Zaradi bližine meje je precejšnja možnost zaposlitve $v$ Italiji in tudi pogosta, s tem pa je povezana tudi potreba po poznavanju navad in postopkov, povezanih $s$ pridobitvijo take zaposlitve. Na tej stopnji se študent seznani $\mathrm{z}$ načini in posebnostmi zaposlovanja $\vee$ Italiji ter $\mathrm{s}$ postopkom prijave na prosto delovno mesto.

Cilj te enote je, da zna študent napisati prošnjo za službo in življenjepis $\mathrm{v}$ obliki, ki jo zahteva sodobna praksa zaposlovanja $\mathrm{v}$ Italiji.

\section{Struktura učnih enot}

Na naslednji stopnji je bilo treba predvideti vsebinsko in oblikovno strukturo uěnih enot. Pri tem smo morali izhajati iz zakonitosti jezikovnega poučevanja tudi iz zakonitosti za pripravo gradiv za samostojno učenje.

Ta notranja struktura se ponovi v vseh učnih enotah in omogoča študentu boljši pregled nad gradivom. Ti deli študijskega gradiva so bili v celoti predvideni v italijanskem jeziku. Pri sestavljanju in pisanju posameznih enot smo izhajali iz gradiva, ki smo ga v preteklih letih uporabili in preizkusili pri delu $\mathrm{z}$ rednimi in izrednimi študenti. Osnova so bili dialogi in besedila iz učbenika N. Cherubini, ki smo jim dodali druge članke, besedila, komentarje in lastne vaje za utrjevanje ter preverjanje znanja.

Poleg tega smo za utrjevanje snovi in kot pripravo na izpit predvideli tudi tri preizkusne naloge, ki zaokrožajo učno snov več enot 
Vsako učno enoto sestavljajo:

- nova učna snov (teoretične ali praktične vsebine), ki predstavi ali ponazori temo učne enote; gre za kratke dialoge (prva, četrta in peta enota), za primere dopisov (druga, tretja, šesta, sedma enota), hkrati pa še za kratko teoretično uvodno besedilo (druga, šesta, sedma enota);

- komentarji s pojasnili neznanih pojmov in izrazov iz strokovnega dela, ki nadomestijo razlago učitelja pri delu $v$ skupini, in slovarček novih besed;

- praktični primeri, naloge in vaje za utrjevanje snovi;

- naloge in vaje za preverjanje znanja in povratno informacijo; vaje so namenjene utrjevanju nove učne snovi in jezikovnih struktur (predvsem slovničnih), ki se $\mathrm{v}$ določenih okoliščinah pojavljajo in jih je treba obvladati za pravilno razumevanje in izražanje; za vse naloge in vaje so na koncu učbenika navedene tudi rešitve;

- članki in krajša besedila s področja ekonomije, gospodarskega prava in poslovne kulture, ki so vključeni na koncu vsake učne enote; njihov namen je dodatno razširiti in poglobiti besedni zaklad ter poznavanje nekaterih področij, povezanih s poslovanjem.

(dveh ali treh) in za katere $v$ učbeniku ni rešitev. Študent naj bi jih poslal svojemu mentorju, ta bi jih pregledal in napisal svoje komentarje glede napak in pomanjkljivosti. S tem bi dobil študent povratno informacijo o svojem delu, obenem pa nasvete in navodila za pripravo na končni izpit.

\section{GRAFIČNA PONAZORITEV IN IZBIRA VIROV}

Grafična ponazoritev in ureditev besedil ter vaj ima $v$ gradivu za samostojno učenje posebno didaktično funkcijo. Ker študent skozi učno snov napreduje sam, mora gradivo ne le vsebinsko, ampak tudi oblikovno prevzeti določene funkcije, ki jih ima pri neposredni komunikaciji v skupini mentor, in sicer kar zadeva ponazoritev snovi ali navodila za delo, pa tudi njegovo mimiko in geste, dinamiko govora in nastopa.

Oblikovno je to mogoče različno doseči: $\mathrm{z}$ obliko in velikostjo črk, razmakom med vrsticami, poudarjenim in poševnim tiskom, uokvirjanjem besedila, ilustracijami in karikaturami, grafično ponazoritvijo učne snovi ipd. Tudi vezano besedilo je mogoče narediti vizualno bolj sporočilno in prijetno za branje s tem, da ga uredimo $v$ več odstavkov, povečamo razmik med vrsticami, naredimo večji rob na zunanji strani, kar študentu omogoča pisanje pripomb ipd. Pomembno je, da besedilo "diha" in daje občutek zračnosti in odprtosti. Gosto popisane, nabite strani so za branje ter študij zelo naporne in odbijajoče.

Pomembno je, da se struktura sestavnih delov učne enote ponovi $\mathrm{v}$ vseh učnih enotah. Podobno didaktično funkcijo imajo tudi oblikovni elementi in simboli ter oznake za boljši pregled (oštevilčenje strani, glava/noga, kazalo ipd.). Študenta vodijo skozi učno enoto in mu dajejo pregled nad različnimi tipi besedil in dejavnosti, predvsem pa občutek za dinamiko učne enote in s tem celotnega učbenika.

Že pred začetkom pisanja gradiva za italijanski jezik smo se odločili, da bomo gradivo oblikovali sami, ker smo menili, da imamo potrebno znanje in opremo. Predvsem pa smo iz izkušenj vedeli, da bi bilo sodelovanje $\mathrm{z}$ oblikovalcem lahko veliko zamudnejše, saj v fazi priprave učbenikov za prvo generacijo nismo imeli dovolj dobro usposobljenega oblikovalca, ki bi poznal principe oblikovanja gradiva za samostojni študij in obvladoval italijanski jezik, kar je 
pomenilo, da bi moral skoraj $\mathrm{v}$ celoti delati po naših navodilih. To nam je obenem omogočalo, da do konca spreminjamo in dopolnjujemo gradivo, ki bi ga morali sicer oddati v oblikovanje že mesec dni prej, tako da bi bile zaradi postavitve besedila $\mathrm{v}$ računalniku večje spremembe nemogoče.

\section{Izbira medijev in dodatnih virov za dopolnitev gradiva}

Pri jezikovnem izobraževanju je treba za razvijanje slušnega razumevanja in ustnega izražanja $\mathrm{v}$ študijsko gradivo vključiti tudi avdio- ali videoposnetke, ki študentu omogočajo vsestranski stik z jezikom, ki se ga uči. Ker smo že za pripravo učbenika imeli malo časa in ker za pripravo avdio- in videoposnetkov nismo imeli na voljo posebnih sredstev, smo se že v začetku odločili, da pri pripravi prve različice gradiva ne bomo vključili avdio- in videoposnetkov, ampak bomo izrabili geografske okoliščine - bližino italijanske meje in $s$ tem dostopnost italijanskega radia in televizije, tiska in drugih medijev. Študente smo na uvodnem srečanju na to posebej opozorili in jim svetovali, kako naj te vire in medije uporabljajo.

Bližina italijanske meje in s tem dostopnost italijanskih medijev in možnost osebnih stikov z Italijani se je že v preteklosti izkazala za dragoceno podporo in ozadje pri študiju poslovnega italijanskega jezika. Medtem ko so mlajše generacije preko radia in televizije razvile zelo dobro razumevanje in preko prijateljskih in sorodstvenih stikov tudi sproščenost pri sporazumevanju, so imeli študenti srednje generacije pogosto dragocene praktične izkušnje pri poslovanju $\mathrm{z}$ italijanskimi kupci in dobavitelji.

Te prednosti in izkušnje so bile zelo pomembne, zato smo iz njih tudi izhajali. Izkazalo se je, da so študentje, ki so imeli izkušnje pri delu z italijanskimi partnerji, zlahka in uspešno dopolnjevali svoje učenje na konkretnih primerih iz svojega delovnega okolja in jim je bilo napredovanje skozi snov pravi užitek. Dragoceni vir učenja so bile prav njihove lastne izkušnje, ki so jih pri učenju lahko povezali $v$ nova spoznanja o načinih komunikacije $\mathrm{z}$ italijanskimi sodelavci in partnerji. Tako se je formalni študij dopolnjeval $\mathrm{z}$ neformalnimi oblikami.

\section{IZVEDBA IZOBRAŽEVANJA IN EVALVACIJA}

Študij primera je trajal pet let (1995-2000). V tem času je šlo za sistematično zbiranje povratnih informacij, na podlagi katerih so bili pripravljeni predlogi za novo različico študijskega gradiva.

Posebnost izvedbe programa poslovnega italijanskega jezika na daljavo je bila $v$ tem, da kot avtorji programa in gradiva pravzaprav nismo vedeli, kako bo izobraževanje $\mathrm{v}$ resnici potekalo in kakšni bodo rezultati. Prva generacija študentov na daljavo se je namreč vpisala, ko je bilo gradivo že pripravljeno. Študente smo srečali pred začetkom izvajanja predmeta, vendar je šlo za zelo formalno srečanje, pri katerem ni bilo mogoče navezati tesnejših stikov. Omejili smo se predvsem na to, da smo jim dali temeljna navodila za študij in jih spodbudili $\mathrm{k}$ delu, jim svetovali uporabo dodatnih virov in jih opozorili na možnost konzultacij z nosilcem predmeta in mentorjem v centru.

Pomoč študentom pri študiju je bila predvidena kot tedenska srečanja $\mathrm{z}$ mentorjem $v$ študijskem centru, individualne konzultacije $\mathrm{z}$ mentorjem $\mathrm{v}$ centru in telefonske konzultacije $\mathrm{z}$ mentorjem ali nosilcem predmeta. Študenti so se razdelili v tri skupine. Prvi dve skupini je prevzela mentorica ${ }^{2}$ iz centra v Novi Gorici (NG), tretja skupina (približno petnajst študentov) pa je študirala povsem samostojno in je bila $v$ 
stiku z nosilcem predmeta (avtorjem študijskega gradiva). Tako je bilo delo študentov mogoče spremljati posredno prek mentorice v Novi Gorici, ki se je s študenti srečevala enkrat na teden, neposredno pa pri delu s tretjo skupino študentov, ki je študirala povsem na daljavo, saj so bili v stiku z mano le prek študijskega gradiva in po telefonu.

\section{Profil študentov}

Dejansko se je ob vpisu prve generacije izkazalo, da gre za zelo mlade slušatelje (mlajše, kot smo pričakovali), prevladovali so mladi, ki so se za ta način študija odločili takoj po srednji šoli in so bili po večini meril primerljivi z rednimi študenti (študij je bila njihova primarna dejavnost, živeli so pri starših, ki so jim tudi plačali šolnino, niso bili zaposleni ali so opravljali le priložnostno delo, šola je za večino pomenila izhod pred brezposelnostjo). Pravih lastnosti odraslega študenta, kot so izkušnje, predstava o sebi, prostovoljnost pri odločanju za študij ipd., še niso razvili.

Potrdile so se tudi predpostavke glede predznanja italijanskega jezika ter glede predhodne izobrazbe in razlik $\mathrm{v}$ razvitosti učnih navad ter tehnik učenja, pripravljenosti za izobraževanje in motivaciji. Velik problem prve generacije je bila namreč izrazita pasivnost: študenti prvih dveh skupin so mislili, da jim bo mentorica predavala snov. Kljub vztrajnim opozorilom, da so srečanja z mentorjem namenjena reševanju nejasnih vprašanj in poglabljanju snovi, je večina do konca prihajala na srečanja povsem nepripravljena.

Precej drugače pa je potekalo delo s tretjo skupino. Ti študenti so se odločili za povsem samostojen študij zato, ker so imeli dobro predznanje in/ali ker zaradi svojih poklicnih in zasebnih obveznosti niso hoteli biti vezani na urnik v centru. Nekaj vtisov o študentih smo dobili med potekom programa, za-

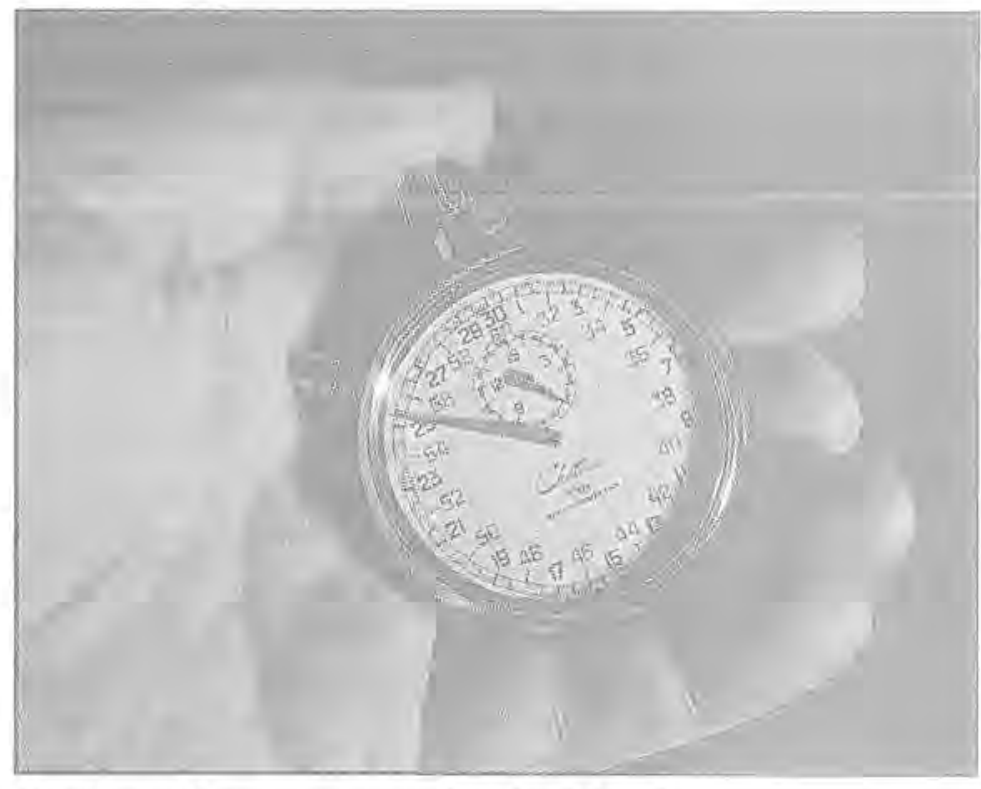

okrožena slika pa se je pokazala šele ob koncu programa, ko smo se s študenti pogovorili o njihovih vtisih. Takrat smo nekatere študente, s katerimi smo prej komunicirali pisno ali po telefonu, prvič srečali tudi osebno.

Študenti tretje skupine so se izkazali za "prave" študente na daljavo in so imeli vse karakteristike odraslih $\mathrm{v}$ izobraževanju: njihov odnos do študija je bil dinamičen in vpet $\mathrm{v}$ druge dejavnosti in obveznosti, ki so jih imeli. Študij je bil za vse sekundarna dejavnost, čeprav so bili nekateri stari šele devetnajst let in niso imeli svoje družine (skoraj polovica jih je živela še pri starših). Za študij so bili zelo motivirani, vsi so se zavedali, da za napredovanje $\mathrm{y}$ poklicu potrebujejo širše, bolj poglobljeno znanje.

\section{Primernost izbranih vsebin}

Veliko študentov, ki so se pri svojem delu že srečali z italijanskim poslovnim okoljem, je potrdilo, da so se dejansko srečali $s$ podobnimi okoliščinami in da so pri študiju $\mathrm{z}$ velikim zanimanjem primerjali svoje izkušnje s predstavljenimi primeri. Nekateri so svoje 
na novo pridobljeno znanje celo že uporabili pri delu (korespondenca, predstavitve) in so bili na to zelo ponosni, sposobni pa so bili tudi primerjati svoje predhodno znanje $\mathrm{z}$ novim. Tudi tisti, ki z italijanskim poslovnim okoljem niso imeli stikov, so menili, da bodo pridobljeno znanje lahko koristno uporabili, če bodo morali na primer napisati poslovno pismo, predstaviti svoje podjetje ipd.

Kljub začetnemu strahu večina ni imela posebnih težav pri študiju, snov se jim je zdela predstavljena nazorno, razlaga razumljiva in navodila dovolj izčrpna, čeprav v gradivu ni bilo besedila, ki bi izrecno povezovalo posamezne učne stopnje. Največja težava sta bila nezadostno (splošno in jezikovno) predznanje in nerazvitost delovnih navad za samostojni študij. To je kazalo na stopnjo kulturne razvitosti študentov in njihovega okolja.

Splošna ocena prve generacije je bila, da je študijsko gradivo zanimivo in koristno, predvsem pa dovolj praktično zasnovano, da so $v$ njem študenti lahko prepoznali svoje dejanske ali verjetne potrebe pri poslovanju z italijanskim poslovnim okoljem. Veliko študentov je povedalo, da jim je bilo učenje $v$ veselje in da so pridobili veliko koristnega znanja.

\section{Ocena mentorice $v$ študijskem centru}

Mentorica se je pri svojem delu srečala predvsem s študenti s slabim predznanjem in slabo razvitimi delovnimi navadami, ki so mislili, da jim bo na skupinskih srečanjih snov razložena "po šolsko". Povedala je, da je največ energije vložila $v$ to, da te študente pripravi na samostojen način dela. Ta se od študentov na daljavo tudi pričakuje. Za študente, ki niso imeli potrebnega predznanja, so $\mathrm{v}$ centru že pred začetkom izvajanja predmeta organizirali začetne in osvežitvene tečaje, vendar to za nekatere študente ni bilo dovolj, zato so morali učenje splošnega jezika nadaljevati in izpit iz predmeta poslovni italijanski jezik opravljati kasneje.

Mentorica je opozorila tudi na to, da nekateri študenti z razmeroma dobrim predznanjem ta predmet podcenjujejo, saj so prepričani, da glede na sposobnost sporazumevanja, ki so jo razvili v svojem okolju, učenje zanje pravzaprav ni potrebno. Zaradi takega odnosa in strahu pred izpostavljanjem novim okoliščinam se pred učenjem zapirajo, ne napredujejo in pri izpitih dosegajo slabe rezultate. Izkazalo se je, da je treba študente na uvodnem srečanju na to še posebej opozoriti, to pa bi bilo smiselno vključiti tudi $\mathrm{v}$ komentar in navodila $\mathrm{v}$ učbeniku.

Ocena glede izbire vsebin je bila zelo pozitivna. Tudi pri delu mentorice s študenti se je pokazalo, da teme dejansko ustrezajo okoliščinam, $v$ katerih se znajdejo ali se bodo znašli študentje pri svojem poklicnem delu, za primernega se je izkazal tudi način predstavitve in obravnavanja teh tem $\mathrm{z}$ vidika razvijanja jezikovnih in komunikacijskih funkcij. Opazovanja so pokazala, da bi bilo smiselno za skupinska srečanja in samostojno delo pripraviti dodatne vaje (primere s področja ekonomije, poslovne kulture, jezikovne in slovnične vaje). Nekateri študenti, ki niso hodili na skupinska srečanja, so tudi sami izrazili željo po dodatnih vajah za utrjevanje snovi in preverjanje znanja. Dejansko je bilo študijsko gradivo v svoji prvi različici omejeno predvsem na osnovno izbiro besedil in vaj, ki bi mu bilo smiselno dodati več primerov in vaj. Te ugotovitve so bile izhodišče za dopolnjevanje študijskega gradiva.

\section{Vloga preizkusnih nalog}

Preizkusne naloge so se izkazale za zelo dragoceno oporo študentom, predvsem pa 
pomenijo konkretno podlago za svetovalno delo. Na podlagi napak, ki so se pojavile pri reševanju preizkusnih nalog, smo lahko dejansko hitro ocenili, kakšno je študentovo znanje $v$ pogledu splošnih jezikovnih kompetenc in tudi poznavanja poslovnih vsebin. Pogosto so bile preizkusne naloge edina vez med študentom in mentorjem in/ali avtorjem gradiva in že pri prvi generaciji študentov na daljavo se je izkazalo:

- da dajo mentorju dober in celovit vpogled $v$ študentovo znanje in so odlična podlaga za svetovalno delo;

- da dajo študentu predstavo o tem, kaj se je naučil oziroma kakšno znanje si je pridobil, pa tudi to, kaj se od njega pričakuje na izpitu;

- da so za avtorja gradiva dragocena povratna informacija za dopolnjevanje gradiva (pisanje komentarjev $\mathrm{k}$ posameznim aktivnostim, pisanje navodil za reševanje vaj in nalog, priprava dodatnih virov, besedil in vaj ipd.)

Že pri prvi generaciji se je potrdilo, da imajo preizkusne naloge funkcijo sprotnega vrednotenja in tudi funkcijo prognostičnega testa, saj so rezultati preizkusnih nalog že dokaj jasno napovedovali rezultate pri končnem testu. Preizkusne naloge so namreč pokazale študentovo splošno jezikovno znanje, pa tudi poznavanje zakonitosti italijanščine v poslovnem okolju.

1. Če so imeli študenti slabo znanje splošnega jezika, vendar so poslovne vsebine dobro predelali, je bilo iz preizkusnih nalog že mogoče sklepati, kakšni bodo rezultati pri končnem vrednotenju, saj ni bilo mogoče pričakovati, da se bo njihova raven splošne jezikovne kompetence izboljšala (to se je pokazalo predvsem $v$ razmeroma manjši sposobnosti uporabe različnih jezikovnih sredstev in registrov).

2. Če so imeli študenti dobro znanje splošnega jezika, vendar so poslovne vsebine predelali površno, je bilo iz preizkusnih nalog mogoče sklepati, kakšni bodo rezultati pri končnem vrednotenju, če ne bodo upoštevali mentorjevih nasvetov in posameznih enot gradiva predelali temeljiteje.

\section{Preizkusne naloge v učbeniku često odigrajo funkcijo prognostičnega testa.}

\section{SKLEPNE MISLI}

$\mathrm{V}$ petih letih spremljanja in opazovanja se je izkazalo, da je bil pristop $\mathrm{k}$ programiranju primeren, saj so študenti ne glede na obliko, v kateri je potekalo izobraževanje, dosegali primerljive rezultate. Precej zaslug za to ima program izobraževanja na daljavo, zaradi katerega se je bilo treba jasno opredeliti do

Zelo pomembno je spoznanje, da ima neposredno delo $v$ skupini vsekakor prednosti in je zelo pomembno za razvijanje spretnosti razumevanja ter izražanja $v$ tujem jeziku, ne pomeni pa nujno tudi bolj kakovostnega učenja in odnosa med slušateljem ter predavateljem pri študentih, ki so sposobni samostojnega izobraževanja. Samostojen študij na podlagi dobro pripravljenega študijskega gradiva in učinkovitega mentorskega in svotovalnega dela lahko privede do boljših rezultatov kot delo $v$ tečajni obliki, vendar morajo biti vsebine jasno in operativno definirane glede na cilje, ki jih želimo s poučevanjem/učenjem doseči. Pri izobraževanju na daljavo je ta pogoj neizogiben, pri tečajni obliki pa lahko dinamika, ki jo prispeva učitelj s svojim nastopom in metodami dela, preusmeri pozornost $\mathrm{z}$ vsebin in ciljev na metode. 
nekaterih vprašanj, ki navadno ostajajo nerešena: predvsem do vprašanja razmerja med programom (in zastavljenimi cilji) in študijskim gradivom. Vse stopnje izvedbe in vrednotenja je bilo treba jasno in operativno definirati vnaprej in to je pomembno vplivalo tudi na predstavo o programu ter osmišljenosti posameznih učnih enot.

Izkušnje, ki smo jih dobili pri programiranju poslovnega italijanskega jezika na daljavo, so pomembno vplivale na pedagoško delo. Šele pri programiranju učbenika za študij na daljavo se je bilo mogoče zavedati pomena jasne konceptualizacije izobraževalnih ciljev in vsebin ter vloge, ki jo ima pri jezikovnem izobraževanju študijsko gradivo. Če predavatelj tujih jezikov program podredi vsebinam vnaprej pripravljenega gradiva, tem vsebinam dejansko podredi tudi potrebe in želje odraslih slušateljev. To obenem dokazuje, da bi bilo treba pri izobraževanju predavateljev tujih jezikov, ki delajo z odraslimi, več pozornosti posvetiti prav vprašanjem programiranja.

${ }_{1}$ Leta 1998 se je predmetnik prvega letnika spremenil. tuji jeziki so bili prestavljeni v 2. Ietnik.

${ }^{2}$ Stalna mentorica za predmet poslovni italijanski jezik je Nataša Kabaj Bavdaž, ki sicer poučuje na srednji ekonomski šoli v Novi Gorici. Odlično pozna tematiko in problematiko poslovne italijanšcine, predvsem pa tudi okoliššine, v katerih študirajo študenti na daljavo. 